\title{
LEMON GRASS ESSENTIAL OIL (CYMBOPOGUM FLEXUOSUS) IN HIGH- CONCENTRATE DIETS FOR LAMBS
}

\section{Óleo essencial de capim limão (Cymbopogum flexuosus) em dietas com alto teor de concentrado para cordeiros}

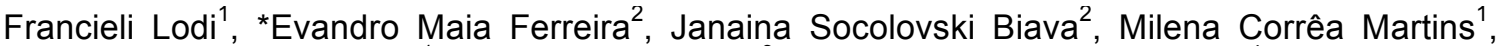
Rhaissa Garcia de Assis ${ }^{1}$, José Luiz Moletta ${ }^{3}$, Leandro Coelho de Araujo ${ }^{4}$, Victor Breno Pedrosa $^{1}$, Daniel Montanher Polizel ${ }^{2}$, Alexandre Vaz Pires ${ }^{2}$

\footnotetext{
${ }^{1}$ Department of Animal Science, State University of Ponta Grossa, Ponta Grossa - Paraná, Brazil, 2Department of Animal Science, "Luiz de Queiroz" College of Agriculture, University of São Paulo, ESALQ/USP, Piracicaba - São Paulo, Brazil, ${ }^{3}$ Agronomic Institute of Paraná Experimental Station IAPAR, Ponta Grossa - Paraná, Brazil, ${ }^{4}$ São Paulo State University, School of Engineering, Campus of Ilha Solteira, Ilha Solteira - São Paulo, Brazil.
}

*Corresponding author: evandro.ferreira@usp.br

ABSTRACT: The objective of this study was to evaluate the effect of the inclusion of two doses of monensin and lemon grass essential oil (Cymbopogum flexuosus) on nutrient intake and digestibility, ruminal fermentation and ingestive behavior of lambs fed a high-concentrate diet. Four ruminally cannulated ram lambs $(44.7 \pm 3.72 \mathrm{~kg}$ of BW and approximately 5 mo. old) in a $4 \times 4$ Latin square experimental design were used. The control diet (CONT) contained $15 \%$ of oat hay, $85 \%$ of concentrate and no additives. In the remaining diets it was included $12.5(12.5 \mathrm{MON})$ or $25.0(25 \mathrm{MON})$ $\mathrm{mg} / \mathrm{kg}$ of monensin (as-fed basis) or $1 \mathrm{~mL} / \mathrm{kg}$ of DM of lemon grass essential oil (EO). The treatments had no effect on the nutrient intake and digestibility. The lambs that received the EO treatment showed a higher ruminal $\mathrm{pH}$ in comparison to those that received the control diet. However, they did not differ from treatments with monensin. A quadratic response was observed for ruminal $\mathrm{pH}$, with the highest value observed in the animals fed the diet $12.5 \mathrm{MON}$. The lambs fed $\mathrm{EO}$ had a higher ruminal concentration of acetate than the diet with monensin. There was a quadratic response of monensin on ruminal concentration of acetate, with the lowest value observed for $12.5 \mathrm{MON}$. The acetate:propionate ratio was lower in lambs fed $12.5 \mathrm{MON}$ compared to the control. EO decreased the ruminal concentration of butyrate; however, its concentration was higher in lambs fed monensin than EO diets. A lower concentration of total short chain fatty acids (SCFA) was observed in lambs fed $12.5 \mathrm{MON}$. The alanine aminotransferase (ALT) blood concentration was higher in the lambs fed EO compared to the control. EO increased rumen concentration of blood glucose compared to the treatments containing monensin and decreased the number of eggs per gram of feces (EGF). In addition, there was a quadratic response of monensin on the EGF, with a higher value in the lambs fed 12.5MON. In conclusion, half of the daily dose of monensin was more effective at increasing ruminal $\mathrm{pH}$ than the full dose, with no negative reflection on nutrient intake and digestibility, as well as on the ingestive behavior and parasitic load of the animals. Thus, $12.5 \mathrm{MON}$ may be indicated for lambs feed high concentrate diet. EO proved to be a good natural source to replace ionophores in diets for lambs.

Keywords: additives; high grain diet; ionophores; nutrition. 
RESUMO: O objetivo desse estudo foi avaliar o efeito da inclusão de duas doses de monensina e do óleo essencial de capim limão (Cymbopogum flexuosus) sobre o consumo e digestibilidade dos nutrientes, fermentação ruminal e o comportamento ingestivo de cordeiros recebendo dietas com elevado teor de concentrado. Foram utilizados quatro cordeiros não castrados canulado no rúmen $(44.7 \pm 3.72 \mathrm{~kg}$ de peso médio inicial e aproximadamente 5 meses de idade) em delineamento experimental quadrado latino $4 \times 4$. A dieta controle (CONT) continha $15 \%$ de feno de aveia, $85 \%$ de concentrado, sem aditivos. Nas dietas remanecentes foi incluido $12,5(12,5 \mathrm{MON})$ ou 25,0 (25MON) $\mathrm{mg} / \mathrm{kg}$ de monensina ou $1 \mathrm{~mL} / \mathrm{kg}$ de óleo essencial de capim limão (OE). Não houve efeito dos tratamentos sobre o consumo e digestibilidade dos nutrientes. Os cordeiros que receberam a dieta com $\mathrm{OE}$ apresentaram maior $\mathrm{pH}$ ruminal em comparação aos que receberam dieta controle. Entretanto, eles não diferiram dos tratamentos com monensina. Foi observada resposta quadrática para $\mathrm{pH}$ ruminal, com o maior valor observado para os animais que receberam $12,5 \mathrm{mg} / \mathrm{kg}$ de monensina. Os cordeiros recebendo $\mathrm{OE}$ apresentaram maior concentração de acetato em relação aos alimentados com monensina. Houve resposta quadrática da monensina na concentração ruminal de acetato, com menor valor observado para os animais da dieta $12.5 \mathrm{MON}$. A relação acetato:propionato foi menor para os cordeiros alimentados com a dieta $12.5 \mathrm{MON}$ em relação aos do tratamento controle. OE diminuiu a concentração ruminal de butirato; entretanto, sua concentração foi maior nos cordeiros que receberam monensina em relação aos que receberam OE. A menor concentração de ácidos graxos de cadeia curta (AGCC) foi observada nos cordeiros alimentados com a dieta 12.5MON. A concentração de alanina aminotransferase (ALT) no sangue foi maior para os cordeiros que receberam OE quando comparados com os do tratamento controle. OE aumentou a concentração de glicose sanguínea comparado ao tratamento contendo monensina e diminuindo o número de ovos por gramas de fezes (OPG). Em adição houve uma resposta quadrática de monensina na OPG, com maior valor nos cordeiros alimentados com a dieta 12.5MON. Em conclusão, a metade da dose diária de monensina foi mais eficiente em aumentar o pH ruminal que a dose inteira, sem efeito negativo na ingestão e digestibilidade dos nutrientes, bem como no comportamento ingestivo e carga parasitária dos animais. Então, 12.5 $\mathrm{mg} / \mathrm{kg}$ de monensina pode ser indicada para cordeiros alimentados com dietas com alto teor de concentrado. O OE mostrou ser uma boa fonte natural para substituir os ionóforos em dietas para cordeiros.

Palavras-chave: aditivos; dieta alto grão; ionóforos; nutrição. 


\section{INTRODUCTION}

Agriculture, socioeconomic and geographical reasons, remains a relevant activity in the national scenario, but also presents significant developments in the scope of international trade. Brazil has been one of the main countries in the international trade of agricultural products, with emphasis on meat (Abiec, 2016). The great competitiveness of this sector in Brazil is due to several factors, such as: availability of agricultural land, favorable climate, bioenergy potential and research.

Among the categories of sheep, the meat of lambs slaughtered with a maximum of 5 months of age, with body weight around $35 \mathrm{~kg}$ is the one that has the highest acceptance by Brazilian consumers. In order to achieve these goals, feedlot practice has proven feasible (Ferreira et al., 2011a; Ferreira et al., 2014; Gastaldello Jr et al., 2013; Maia et al., 2011).

Brazilian research has demonstrated the potential of using high-grain diets for lambs (Ferreira et al., 2014; Gastaldello Jr et al., 2013). Santa Inês lambs presented average daily gain (ADG) of $287 \mathrm{~g} / \mathrm{d}$ and feed efficiency (FE) of 0.25 when fed a diet containing $90 \%$ of concentrate (Ferreira et al., 2014).

However, it is important to highlight that the provision of high non-fiber carbohydrate (NFC) diets increases the risk of metabolic disorders, such as acidosis (Krause and Fotzel, 2006). Ferreira et al. (2011a) found that lambs fed a diet containing $90 \%$ of concentrate presented 5.8 ruminal $\mathrm{pH}$, which is already considered a subclinical acidosis (Santos, 2011). Therefore, it is important to develop nutritional strategies that minimize the risk of metabolic disorders in lamb receiving high concentrate diets.

Monensin has been used by many authors in high-concentrate diets $>80 \%$ of DM) for feedlot lambs, in order to ensure adequate ruminal health, ADG and FE (Ferreira et al., 2011a; Gastaldello Jr et al., 2010; Gastaldello Jr et al., 2013; Ferreira et al., 2014).

In all of these trials, monensin was included in the diet at concentrations ranging from $25 \mathrm{mg} / \mathrm{kg}$ (Ferreira et al., 2011a; Ferreira et al., 2014) to $30 \mathrm{mg} / \mathrm{kg}$ of diet (as-fed basis) (Gastaldello Jr et al., 2010; Gastaldello Jr et al., 2013), which is the amount historically used in diets for beef cattle (Perry et al., 1976; Boucqué et al., 1982). In this sense, it has been hypothesized that in diets for lambs the concentration of monensin may be lower than those classically used.

Alternatively, some essential oils have a similar capacity to ionophores, to act selectively on the microbial populations of the rumen (Calsamiglia et al., 2007), altering the fermentation pattern, reducing the acetate:propionate ratio and methane production, which can make the rumen more efficient. From the in vitro evaluation of lemon grass essential oil (Cymbopogum flexuosus), the antimicrobial effect of this substance has been shown to be clear (Araujo, 2010). Between the effects observed by this author, the decrease in the concentration of acetate, propionate and in the methane production stand out. It is widely known that the production of $\mathrm{CH}_{4}$ generates energy losses to the animal, ranging from 2 to $12 \%$ of the total gross energy consumed (Van Soest, 1994). Therefore, dietary strategies that decrease methane production have great potential for improving feed efficiency. Thus, there is a need for in vivo trials to investigate the effects of lemon grass essential oil on ruminal fermentation.

The hypotheses of this study are (i) that only $12.5 \mathrm{mg} / \mathrm{kg}$ of diet of monensin (half-dose) is sufficient to maintain adequate ruminal $\mathrm{pH}$ of lambs fed highconcentrate diets and that (ii) the lemon grass essential oil will present 
modulating effect of ruminal fermentation similar to monensin. The objectives were to determine the effects of monensin at low concentration (12.5 $\mathrm{mg} / \mathrm{kg} \mathrm{NM}$ ) and lemon grass essential oil on nutrients intake and digestibility, ruminal fermentation and ingestive behavior of lambs fed high-concentrate diets.

\section{MATERIALS AND METHODS}

\section{Local, animals and experimental facilities}

The experiment was conducted at Agronomic Institute of Paraná Experimental Station - IAPAR, located in the city of Ponta Grossa - Paraná, $\left(25^{\circ}\right.$ $05^{\prime} 42^{\prime \prime} \mathrm{S}$ and $50^{\circ} 09^{\prime} 43^{\prime \prime} \mathrm{W}$, Brazil. All animal used procedure followed the guidelines recommended by Animal Care and Use Committee at State University of Ponta Grossa (CEUA/UEPG, Process 027/2016).

Four ruminally cannulated ram lambs (44.7 $\pm 3.72 \mathrm{~kg}$ of $\mathrm{BW}$ and approximately 5 mo old) were used. The animals were surgically prepared for cannula (made of rubber, i.d. $50.8 \mathrm{~mm}$; Kehl, São Carlos, SP, Brazil) placement one month before the beginning of the experiment. After the wounds healed, the animals were placed in a metabolism crates $(1.3 \times 0.55 \mathrm{~m})$ that were fitted with a feeding trough, drinking trough, and a system for collecting feces and urine. The metabolism crates were kept in an indoor environment that was protected from rain and direct sunlight. All animals were dewormed with levamisole hydrochloride (Ripercol, Fort Dodge Animal Health, Campinas, SP, Brazil) at a dose of $5 \mathrm{mg} / \mathrm{kg}$ of BW and were given $2 \mathrm{~mL}$ of ADE vitamin supplements (A-DE, Zoetis Indústria de Produtos Veterinários Ltda, Guarulhos, SP, Brazil) before the start of the experiment.

\section{Experimental designs and treatments}

The experimental period lasted for 64 days and was divided into four 16- days sub-periods. During this time, 10 days were used for animals' adaptation to the experimental diets, four days for measuring the dry matter intake (DMI) and collecting feces and urine, one day for collecting ruminal contents, and one day to evaluate the ingestive behavior. The lambs were assigned in a $4 \times 4$ Latin square experimental design, with 4 treatments and 4 replicates.

The treatments were defined by the addition of 12.5 (12.5MON) and 25.0 (25MON) $\mathrm{mg} / \mathrm{kg}$ of diet of monensin (asfed basis) (Rumensin, Elanco Animal Health, Greenfield, IN), $1 \mathrm{~mL} / \mathrm{kg}$ DM of lemon grass essential oil (EO) to a base diet containing $850 \mathrm{~g} / \mathrm{kg}$ DM of concentrate and $150 \mathrm{~g} / \mathrm{kg}$ DM of oat hay, and control (CONT; base diet without addition of monensin or essenctial oil).

Diets were formulated to meet NRC (2007) recommendations for growing lambs on an average daily gain of $300 \mathrm{~g} / \mathrm{d}$. The proportion of the ingredients and chemical composition of the experimental diets are presented in Table 1.

\section{Feed management and samples collection}

Diets were weighed separately on an electric scale with an accuracy of $1 \mathrm{~g}$ (Marte, LC 100, São Paulo, Brazil), mixed, and offered ad libitum at 10:00 a.m. in the form of total mixed ration. The DMI was recorded from day 11 through day 14. The orts were weighed at the same time the following day to obtain the DMI per animal. Amounts of feed offered to animal were calculated according to previous DMI, and adjustments were made when needed so that refused feed did not exceed 100 $\mathrm{g} / \mathrm{kg}$ of daily intake. Feed and orts from each lambs were sampled and immediately stored at $-18^{\circ} \mathrm{C}$. Feces were individually collected every day using collection bags to avoid urine contamination. After weighing, feces were sampled and immediately stored at $-18^{\circ} \mathrm{C}$. 
Table 1 - Proportions of ingredients and chemical composition of the experimental diets, $\mathrm{g} / \mathrm{kg}$ DM.

\begin{tabular}{|c|c|c|c|c|}
\hline \multirow{2}{*}{ Item } & \multicolumn{4}{|c|}{ Treatments $^{\top}$} \\
\hline & CONT & 12.5MON & $25 M O N$ & EO \\
\hline \multicolumn{5}{|l|}{ Ingredients } \\
\hline Oat Hay & 150 & 150 & 150 & 150 \\
\hline Ground corn & 665 & 665 & 665 & 664 \\
\hline Soybean meal & 150 & 150 & 150 & 150 \\
\hline Limestone & 15 & 15 & 15 & 15 \\
\hline Mineral Blend ${ }^{2}$ & 15 & 15 & 15 & 15 \\
\hline Urea & 5 & 5 & 5 & 5 \\
\hline Essential oil $^{3}$ & - & - & - & 1.0 \\
\hline Monensin ( $\mathrm{g} / \mathrm{kg}$ of diet) & - & 0.125 & 0.250 & - \\
\hline \multicolumn{5}{|l|}{ Chemical composition } \\
\hline Dry matter (g/kg OM $\left.{ }^{4}\right)$ & 903 & 891 & 900 & 891 \\
\hline Organic matter & 950 & 950 & 950 & 960 \\
\hline Crude protein & 131 & 140 & 131 & 131 \\
\hline Ethereal Extract & 23 & 24 & 20 & 22 \\
\hline Neutral detergent fiber & 291 & 309 & 325 & 285 \\
\hline Non-Fiber carbohydrates & 504 & 480 & 469 & 522 \\
\hline
\end{tabular}

${ }^{1}$ CONT $=$ without addition of monensin or lemon grass essential oil; $12.5 \mathrm{MON}=12.5 \mathrm{mg} / \mathrm{kg}$ of diet of monensin; $25 \mathrm{MON}=25 \mathrm{mg} / \mathrm{kg}$ of diet of monensin; $E O=1 \mathrm{~mL} / \mathrm{kg}$ DM of lemon grass essential oil.

2 Composition: $120 \mathrm{~g}$ of calcium, $32 \mathrm{mg}$ of cobalt, $15 \mathrm{~g}$ of sulfur, $758 \mathrm{mg}$ of iron, $880 \mathrm{mg}$ of fluorine, $65 \mathrm{~g}$ of phosphorus, $111 \mathrm{mg}$ of iodine, $2,700 \mathrm{mg}$ of manganese, $16 \mathrm{mg}$ of selenium, $160 \mathrm{~g}$ of sodium, 2,280 $\mathrm{mg}$ of zinc.

${ }^{3}$ Lemon grass essential oil.

${ }^{4}$ Organic matter

\section{Ruminal SCFA and $\mathrm{pH}$}

Samples of ruminal fluid were collected by hand on day 15 of each experimental period. Samples were collected at $0,3,6,9$ and $12 \mathrm{~h}$ after feeding. At each interval, a representative sample of ruminal contents was collected from each animal via the cannula, which was rapidly filtered through nylon cloth for 37 yield of approximately $200 \mathrm{~mL}$ of ruminal fluid, which was then used to measure the $\mathrm{pH}$ in a potentiometer (Tecnal, TEC 2, São Paulo, Brazil). The solid phase of the ruminal contents that remained in the tissue after filtration was immediately returned to the rumen. After the $\mathrm{pH}$ was determined, two $25 \mathrm{~mL}$ aliquots of ruminal fluid were reserved, stored in plastic vials, and frozen at $-18^{\circ} \mathrm{C}$ for subsequent total short chain fatty acids (SCFA) analysis.
Ingestive behavior

On days 16 of each experimental sub-period, the ingestion behavior observations for each lamb were visually recorded every $5 \mathrm{~min}$ for $24 \mathrm{~h}$. Two trained observers were used for each 3hour interval, and each observer was responsible for recording the ingestive behavior. This was accomplished by making point-in-time observations as described by Araujo et al. (2008). Eating, ruminating, and total chewing times were determined and expressed as minutes per day. Time (expressed in minutes) expended in each activity was calculated by the number of observations recorded multiplied by 5 . Total chewing time was considered the sum of eating and ruminating times (Weidner and Grant, 1994). Eating, ruminating, and total chewing times were also expressed as minutes per gram of DMI and NDF intake.

\section{Biochemical characteristics and erythrogram}

On days 15 of each experimental sub-period, two blood samples from each lamb were collected from the jugular vein puncture. The blood was collected intro Vacutainer tube with serum-inert separator gel and clot activator (VACUETTE of Brazil, Campinas, SP, Brazil) and in Vacutainer tube with EDTA as anticoagulant (VACUETTE of Brazil, Campinas, SP, Brazil). The samples were duly identified, kept under refrigeration in a thermal box containing ice and sent for biochemical analysis in the LLT Veterinary Laboratory (Ponta Grossa, $P R$, Brazil) in order to determine ALT, Glucose, Urea, red blood cells, hemoglobin and hematocrit.

\section{Parasitological analysis}

On day 16 of each experimental sub-period, four hours after feeding, fecal samples were collected directly into the rectal ampulla of each lamb. Immediately after collection, the samples 
were packed in plastic bags, identified and sent under refrigeration to the Laboratory of Parasitology for analysis (UEPG) of eggs per gram of feces (EGF), according to the technique described by Gordon and Whitlock (1939).

\section{Laboratory analysis and calculations}

Samples of feed, orts and feces were ground through a $1.0 \mathrm{~mm}$ Wiley Mill screen (MARCONI, Piracicaba, SP, Brazil). The final dry matter (DM) content was determined after oven-drying the samples at $105^{\circ} \mathrm{C}$ for $24 \mathrm{~h}$ according to the method of the Association of Official Analytical Chemists (AOAC, 1990; \#934.01). Organic matter (OM) was determined by difference after heating the samples in muffle furnace at $550^{\circ} \mathrm{C}$ for 4h (AOAC, 1990; \#942.05). Total nitrogen $(\mathrm{N})$ concentration was determined using a Leco FP-528 Total Nitrogen Analyzer (LECO Corporation, St. Joseph, MI, USA; 1990; AOAC, \#968.06). Crude protein (CP) was obtained by multiplying the total $\mathrm{N}$ content by 6.25 . Neutral detergent fiber (NDF) was determined according to Van Soest et al. (1991) using heat-stable alpha-amylase and sodium sulfite, and acid detergent fiber (ADF) according to AOAC (1990; \#954.01) with an Ankom A200 Fiber Analyzer (ANKOM Tech. Corp., Macedon, NY, USA). The ether extract (EE) was determined using a LECO TFE-2000 Fat Analyzer (LECO Corporation, St. Joseph, MI, USA).

Non-fiber carbohydrates (NFC) were estimated according to the equation: $\mathrm{NFC}=100-(\mathrm{NDF}+\mathrm{CP}+\mathrm{EE}$ $+\mathrm{MM})$. The total digestible nutrient (TDN) were calculated according to Weiss et al. (1992) by using the following equation: TDN $=\mathrm{CP}$ digestible + (lipids digestible $\times 2.25)+$ NDF digestible + NDF digestible. The data to calculate dietary metabolizable energy (ME) were obtained from Weiss et al. (1992).

The SCFA concentration was determined according to Ferreira et al.
(2016) with a colorimetric method, adapted for a microplate reader (EON, Bio Tech Instruments, Winooski, VT, EUA) with a $550 \mathrm{~nm}$ absorbance filter.

\section{Statistical analysis}

Data on the intake, nutrient digestibility, and ingestive behavior were analyzed using the SAS (1999) MIXED procedure according to the model: $Y=\mu$ $+A_{i}+D_{J}+P_{k}+e_{i j k}$, where $\mu=$ mean, $A i$ $=$ effect of animal ( $i=1$ to 4$), \mathrm{Dj}=$ effect of diet $(j=1$ to 4$), P_{k}=$ effect of period $(k$ $=1$ to 4 ), and $e_{\mathrm{ijk}}=$ experimental error. Ruminal measures were also analyzed as repeated measures over time by using the SAS (1999) MIXED according to the following statistical model: $Y=\mu+$ $A_{i}+D_{J}+T_{K}+(D T) j k+P_{l}+e_{i j k l}$, where $\mu=$ mean, $A_{i}=$ effect of animal $(i=1$ to $4), D_{J}=$ effect of diets ( $j=1$ to 4$), T_{K}=$ effect of hours after feeding ( $k=1$ to 4 ), (DT)jk = effect of the interaction between dies and hours after feeding, $\mathrm{P}_{1}=$ effect of period ( $\mathrm{I}=1$ to 4$)$ and eijkl = experimental error. The averages of each treatment were obtained using the LSMEANS command. There were two contrast previously defined: 1 - control diet (CONT) vs. diet containing EO and 2 - CONT vs. diets containing monensin. The effects of inclusion of increasing doses of monensin in the diets were evaluated by linear or quadratic orthogonal polynomials. The effects were considered significant when $\mathrm{P}<0.10$.

\section{RESULTS}

\section{Dry matter and nutrient intake}

All diets showed similar chemical composition, which was already expected considering that they differed only in the type of additive used (Table 1). The dry matter and nutrient intake did not differ between treatments (Table 2).

\section{Nutrient digestibility}

There was no effect of the treatments on the digestibility of DM and 
$\mathrm{OM}$, as well as on the digestibility of nutrients (Table 2).

\section{Ruminal SCFA and $\mathrm{pH}$}

There was no interaction between the treatments and the hours after feeding for the ruminal fermentation characteristics (Table 3 ).

The lambs fed with EO had higher ruminal $\mathrm{pH}(\mathrm{P}=0.06)$ than those fed the control treatments; however, when EO was compared with diets containing monensin there was no difference. Increasing doses of monensin affected quadratic $(\mathrm{P}=0.02)$ ruminal $\mathrm{pH}$, with the highest value observed for $12.5 \mathrm{MON}$. Figure 1 it can be observed that the inclusion of $12.5 \mathrm{mg} / \mathrm{kg}$ of diet of monensin kept the ruminal $\mathrm{pH}$ more stable throughout the hours after feeding.

The lambs that received the diet with EO presented higher $(P=0.09)$ ruminal concentration of acetate compared to those fed with the diets added with monensin, however, when compared to the control treatment, EO did not affect the ruminal concentration of acetate. The effect of monensin contents on the ruminal concentration of acetate were fitted with quadratic regressions with a lower value being observed for $12.5 \mathrm{MON}$. There was no effect of treatments on ruminal concentration of propionate. On the other hand, the acetate:propionate ratio showed a quadratic effect, showing a lower value in the lambs fed with 12.5MON. The EO did not change the acetate:propionate ratio (Table 3 ).

In comparison to the control treatment, the EO $(P<0.01)$ decreased the ruminal concentration of butyrate. However, the concentration of butyrate was higher $(\mathrm{P}=0.09)$ in lambs receiving EO compared to monensin treatments. There was a quadratic $(P<0.001)$ response in the ruminal concentration of butyrate with increasing doses of monensin, with a lower concentration of butyrate in lambs fed with $12.5 \mathrm{MON}$.
Table 2 - Intake and apparent digestibility of nutrients in lambs fed the experimental diets.

\begin{tabular}{|c|c|c|c|c|c|c|c|c|c|}
\hline \multirow{2}{*}{ Item $^{1}$} & \multicolumn{4}{|c|}{ Trataments ${ }^{2}$} & \multirow{2}{*}{$\mathrm{SEM}^{3}$} & \multicolumn{4}{|c|}{ Effect" } \\
\hline & CONT & $12,5 \mathrm{MON}$ & $25 \mathrm{MON}$ & EO & & $\begin{array}{l}\text { CONTEO } \\
\end{array}$ & MON*EO & $\mathrm{L}$ & $Q$ \\
\hline Intake, $\mathrm{kg} / \mathrm{d}$ & & & & & & & & & \\
\hline & $\begin{array}{l}1.405 \\
1.38\end{array}$ & $\begin{array}{l}1.222 \\
1.165\end{array}$ & $\begin{array}{l}1.491 \\
1.424\end{array}$ & $\begin{array}{l}1.352 \\
1.310\end{array}$ & 0.066 & 0.86 & 0.98 & 0.88 & 0.67 \\
\hline $\begin{array}{l}\mathrm{OM} \\
\mathrm{CP}\end{array}$ & $\begin{array}{l}1.338 \\
0.190\end{array}$ & $\begin{array}{l}1.165 \\
0.171\end{array}$ & 199 & $\begin{array}{l}1.130 \\
0.178\end{array}$ & 0.01 & 0.78 & 0.82 & 0.88 & 0.70 \\
\hline NDF & 0.412 & 0.382 & 491 & 0.387 & 0.02 & 0.78 & 0.48 & 0.73 & 0.67 \\
\hline NFC & 0.707 & 0.585 & 0.709 & 0.714 & 0.03 & 0.96 & 0.59 & 0.97 & 0.66 \\
\hline & 0.029 & 0.026 & 0.024 & 0.031 & 0.01 & 0.82 & 0.47 & 0.92 & 0.86 \\
\hline TDN & 1.148 & 1.004 & 1.227 & 1.107 & 0.06 & 0.87 & 0.96 & 0.83 & 0.63 \\
\hline Digestibility, kg/d & & & & & & & & & \\
\hline $\begin{array}{l}\text { DM } \\
O M\end{array}$ & 0.84 & & & 0.82 & & & & $\begin{array}{l}0.45 \\
0.47\end{array}$ & $\begin{array}{l}0.65 \\
0.65\end{array}$ \\
\hline $\mathrm{CP}$ & 0.78 & $\begin{array}{l}0.85 \\
0.80\end{array}$ & $\begin{array}{l}0.74 \\
0.75\end{array}$ & 0.70 & & & & 0.40 & 0.59 \\
\hline NDF & 0.73 & 0.73 & 0.75 & 0.65 & 0.03 & 0.33 & 0.14 & 0.44 & 0.61 \\
\hline NFC & 0.93 & 0.94 & 0.93 & 0.95 & 0.0 & 0.69 & 0.99 & 0.42 & 0.92 \\
\hline $\mathrm{EE}$ & 0.77 & 0.83 & 0.68 & 0.66 & 0.04 & 0.47 & 0.50 & 0.99 & 0.82 \\
\hline TDN & 0.82 & 0.83 & 0.81 & 0.81 & 0.01 & 0.79 & 0.63 & 0.52 & 0.77 \\
\hline
\end{tabular}

${ }^{1} \mathrm{DM}=$ Dry matter; $\mathrm{OM}=$ Organic matter; $\mathrm{CP}=$ Crude protein; NDF = Neutral detergent fiber; $\mathrm{NFC}=$ Non-fiber carbohydrate; $\mathrm{EE}=$ Ether extract; TDN = Total digestive nutrients.

${ }^{2} \mathrm{CONT}=$ without addition of monensin or lemon grass essential oil; $12.5 \mathrm{MON}=12.5 \mathrm{mg} / \mathrm{kg}$ of diet of monensin; $25 \mathrm{MON}=25 \mathrm{mg} / \mathrm{kg}$ of diet of monensin; $\mathrm{EO}=1 \mathrm{~mL} / \mathrm{kg} \mathrm{DM}$ of lemon grass essential oil.

${ }^{3} \mathrm{SEM}=$ standard error of the mean $(\mathrm{n}=4$ lambs for each diets).

${ }^{4} \mathrm{~L}=$ linear effect; $\mathrm{Q}=$ quadratic effect.

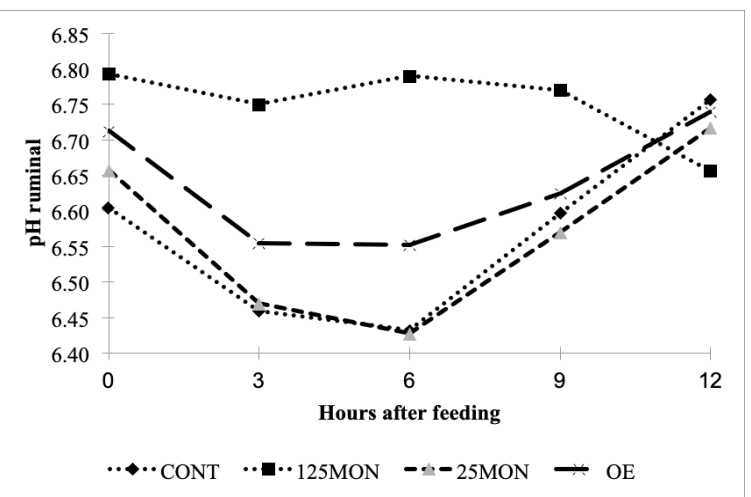

Figure 1 - Ruminal $\mathrm{pH}$ in lambs fed the experimental diets.

In relation to the other treatments, EO increased $(P<0.001)$ the ruminal concentration of valerate. In turn, the supply of increasing contents of monensin linearly $(P<0.01)$ decreases the ruminal concentration of valerate (Table 3).

In the comparison with the control or the monensin treatments, the EO decreased the ruminal concentration of isobutyrate $(P=0.02)$ and of isovalerate $(P<0.001)$. Both fatty acids, isobutyrate $(P=0.09)$ and isovalerate $(P<0.01)$ had their concentrations affected in a quadratic way due to the inclusion of monensin in the diets, with the lowest 
concentrations being observed in the lambs fed with $12.5 \mathrm{MON}$ diet.

EO did not affect the ruminal concentration of SCFA. Additionally, there was a quadratic effect $(P=0.03)$ of monensin on ruminal concentration of SCFA, with a lower concentration to animals fed with 12.5MON (Table 3).

Table 3 - Characteristics of ruminal fermentation in lambs fed the experimental diets.

\begin{tabular}{|c|c|c|c|c|c|c|c|c|c|}
\hline \multirow{2}{*}{ Item } & \multicolumn{3}{|c|}{\begin{tabular}{|l|} 
Trataments' \\
\end{tabular}} & \multicolumn{3}{|c|}{$\mathrm{SEM}^{2}$} & \multicolumn{3}{|l|}{ Effects $^{3}$} \\
\hline & $\overline{\mathrm{CONT}}$ & $12.5 \mathrm{MON}$ & $25 \mathrm{MON}$ & EO & & CONT*EO & MON*EO & $\begin{array}{ll}L \\
\end{array}$ & Q \\
\hline $\mathrm{pH}$ & 6.56 & 6.69 & 6.59 & 6.60 & 0.03 & 0.06 & 0.42 & 0.96 & 0.02 \\
\hline SCFA, $m M$ & & & & & & & & & \\
\hline Acetate & 44.99 & 38.15 & 41.79 & 43.50 & 1.02 & 0.54 & 0.09 & 0.48 & 0.02 \\
\hline Propionate & 35.63 & 31.01 & 31.19 & 32.70 & 1.17 & 0.26 & 0.46 & 0.13 & 0.68 \\
\hline Butyrate & 16.80 & 9.89 & 11.62 & 12.71 & 0.60 & $<0.01$ & 0.09 & $<0.00$ & $<0.001$ \\
\hline Valerate & 1.33 & 1.24 & 1.17 & 1.84 & 0.06 & $<0.001$ & $<0.001$ & $<0.01$ & 0.08 \\
\hline Isobutyrate & 0.89 & 0.77 & 0.92 & 0.67 & 0.03 & 0.01 & 0.02 & 0.53 & 0.09 \\
\hline Isovalerate & 1.26 & 0.96 & 1.40 & 0.79 & 0.06 & $<0.001$ & $<0.001$ & 0.09 & $<0.01$ \\
\hline Total & 100.90 & 82.02 & 88.07 & 92.21 & 2.54 & 0.13 & 0.14 & 0.07 & 0.03 \\
\hline
\end{tabular}

${ }^{1}$ CONT $=$ without addition of monensin or lemon grass essential oil; $12.5 \mathrm{MON}=12.5 \mathrm{mg} / \mathrm{kg}$ of diet of monensin; $25 \mathrm{MON}=25 \mathrm{mg} / \mathrm{kg}$ of diet of monensin; $\mathrm{EO}=1 \mathrm{~mL} / \mathrm{kg} \mathrm{DM}$ of lemon grass essential oil.

${ }^{2}$ SEM = Standard error of the mean.

${ }^{3} \mathrm{~L}=$ linear effect; $\mathrm{Q}=$ quadratic effect.

\section{Ingestive behavior}

The ingestive behavior were not affected by treatments (Table 4).

\section{Biochemical characteristics and erythrogram}

The blood concentration of alanine aminotransferase (ALT) was higher $(P=0.04)$ in the animals that consumed the diet containing EO compared to the control diet. However, there was no difference in the blood concentration of this enzyme between animals receiving $E O$ and those receiving monensin. The monensin contents linearly decreased $(P=0.08)$ ALT concentration (Table 5).

The blood glucose concentration decreased linearly $(P=0.08)$ in response to increasing doses of monensin. EO increased $(P=0.09)$ blood glucose concentration compared to the monensin containing diets. However, blood glucose concentration was similar between animals receiving $\mathrm{EO}$ and control diet (Table 5).
The plasma urea concentration was not affected by the experimental diets (Table 5).

The supply of EO and monensin did not affect the number of red blood cells, hemoglobin concentration and hematocrit of the animals (Table 5).

\section{Parasitological analysis}

EO decreases $(P=0.01)$ the EGF in relation to monensin-containing diets, with no difference in EGF between the animals that received $\mathrm{EO}$ and those who received the control diet. There was quadratic response $(P=0.03)$ in $E G F$ according to inclusion of monensin in the diets (Table 5), with a highest count observed to animals fed $12.5 \mathrm{MON}$ diet.

Table 4 - Ingestive behavior in lambs fed the experimental diets.

\begin{tabular}{|c|c|c|c|c|c|c|c|c|c|}
\hline \multirow{2}{*}{ Item } & \multicolumn{4}{|c|}{ Trataments' } & \multirow[t]{2}{*}{$\mathrm{SEM}^{2}$} & \multicolumn{4}{|c|}{ Effects $^{3}$} \\
\hline & CONT & $12.5 \mathrm{MON}$ & $25 \mathrm{MON}$ & EO & & CONT*EO & MON"EO & $\bar{L}$ & $\bar{Q}$ \\
\hline \multicolumn{10}{|l|}{ Ingesting } \\
\hline Min/d & 229 & 238 & 233 & 195 & 18.80 & 0.63 & 0.48 & 0.79 & 0.95 \\
\hline Min/g DM-1 & 0.14 & 0.15 & 0.19 & 0.17 & 0.02 & 0.70 & 0.99 & 0.86 & 0.99 \\
\hline Min/g NDF-1 & 0.43 & 0.41 & 0.56 & 0.51 & 0.05 & 0.76 & 0.90 & 0.90 & 0.91 \\
\hline \multicolumn{10}{|l|}{ Ruminating } \\
\hline Min/d & 439 & 365 & 490 & 472 & 21.61 & 0.67 & 0.47 & 0.56 & 0.25 \\
\hline Min/g DM"-1 & 0.28 & 0.29 & 0.40 & 0.39 & 0.02 & 0.14 & 0.37 & 0.51 & 0.80 \\
\hline Min/g NDF' & 0.90 & 0.82 & 1.15 & 1.10 & 0.04 & 0.14 & 0.22 & 0.54 & 0.49 \\
\hline \multicolumn{10}{|l|}{ Chewing } \\
\hline Min/d & 668 & 603 & 723 & 667 & 25.89 & 0.99 & 0.96 & 0.75 & 0.33 \\
\hline Min/g DM" & 0.42 & 0.44 & 0.60 & 0.56 & 0.03 & 0.36 & 0.68 & 0.72 & 0.92 \\
\hline Min/g NDF'1 & 1.33 & 1.23 & 1.71 & 1.62 & 0.07 & 0.44 & 0.58 & 0.78 & 0.77 \\
\hline Water & 7.00 & 13.00 & 10.00 & 8.00 & 2.09 & 0.82 & 0.62 & 0.67 & 0.56 \\
\hline Leisure & 763 & 819 & 704 & 764 & 25.57 & 0.99 & 0.97 & 0.74 & 0.40 \\
\hline
\end{tabular}

${ }^{1}$ CONT $=$ without addition of monensin or lemon grass essential oil; $12.5 \mathrm{MON}=12.5 \mathrm{mg} / \mathrm{kg}$ of diet of monensin; $25 \mathrm{MON}=25 \mathrm{mg} / \mathrm{kg}$ of diet of monensin; $E O=1 \mathrm{~mL} / \mathrm{kg} D M$ of lemon grass essential oil.

${ }^{2} \mathrm{SEM}=$ Standard error of the average.

${ }^{3} \mathrm{~L}=$ linear effect; $\mathrm{Q}=$ quadratic effect.

\section{DISCUSSION}

\section{Dry matter and nutrient intake}

The lack of effect of treatments on DMI (Table 2) can be justified by the similarity in the energy density of the experimental diets (Table 1). It is known that in high concentrate diets the DMI is defined by concentration of dietary energy (Nasrollahia et al., 2017) (Table 2). However, considering that monensin normally increases ruminal propionate and decreases methane production (Abrar et al., 2015), which potentially maximizes the efficiency of dietary energy use, it has been widely agreed in 
the literature that addition of monensin in high-concentrate diets reduces DMI (Safaei et al., 2014). Although, the absence of monensin effect on the ruminal concentration of propionate (Table 3) justifies the similarity in DMI.

Table 5 - Biochemical parameters, erythrogram and eggs per gram of feces in lambs fed the experimental diets.

\begin{tabular}{|c|c|c|c|c|c|c|c|c|c|}
\hline \multirow{2}{*}{ Item } & \multicolumn{4}{|c|}{ Trataments' $^{1}$} & \multirow{2}{*}{$\mathrm{SEM}^{2}$} & \multicolumn{4}{|c|}{ Effects $^{3}$} \\
\hline & CONT & $12.5 \mathrm{MON}$ & $25 \mathrm{MON}$ & EO & & $\mathrm{CONT}^{*} \mathrm{EO}$ & MONEEO & $\bar{L}$ & $Q$ \\
\hline $\operatorname{ALT}(U . I / L)^{4}$ & 21.0 & 19.8 & 17.8 & 22.3 & 1.76 & 0.35 & 0.04 & 0.08 & 0.78 \\
\hline Glucose (mg/dL) & 78.3 & 76.8 & 66.0 & 81.0 & 4.48 & 0.58 & 0.09 & 0.08 & 0.43 \\
\hline Urea (mg/dL) & 31.0 & 28.9 & 29.1 & 26.8 & 1.85 & 0.10 & 0.30 & 0.47 & 0.64 \\
\hline Red blood cells. Million/uL & 10.8 & 12.1 & 11.8 & 11.6 & 0.26 & 0.16 & 0.58 & 0.16 & 0.26 \\
\hline Hemoglobin/ $/ \mathrm{L}$ & 11.7 & 11.9 & 12.5 & 11.7 & 0.44 & 1.00 & 0.55 & 0.44 & 0.83 \\
\hline Hematocrit (g/100mL) & 38.6 & 42.5 & 42.3 & 41.6 & 1.09 & 0.22 & 0.68 & 0.19 & 0.44 \\
\hline$E G F^{\circ}$ & 50.0 & 262.5 & 37.5 & 75.0 & 23.44 & 0.23 & 0.01 & 0.97 & 0.03 \\
\hline
\end{tabular}

${ }^{1} \mathrm{CONT}=$ without addition of monensin or lemon grass essential oil; $12.5 \mathrm{MON}=12.5 \mathrm{mg} / \mathrm{kg}$ of diet of monensin; $25 \mathrm{MON}=25 \mathrm{mg} / \mathrm{kg}$ of diet of monensin; $\mathrm{EO}=1 \mathrm{~mL} / \mathrm{kg} \mathrm{DM}$ of lemon grass essential oil.

${ }^{2}$ SEM = Standard error of the mean.

${ }^{3} \mathrm{~L}=$ linear effect; $\mathrm{Q}=$ quadratic effect.

${ }^{4} \mathrm{ALT}=$ Alanine aminotransferase.

${ }^{5} \mathrm{EGF}=$ Eggs per gram of feces.

Similar result was reported by Gastaldello Jr et al. (2010) that compared a non-monensin diet with a diet containing $30 \mathrm{mg} / \mathrm{kg}$ of diet of monensin to feedlot lambs $(90 \%$ concentrate diet) and also did not observe effect on DMI.

The non-effect of the EO on DMI demonstrates the good palatability of this substance. The results of the present experiment reaffirm those verified by Faleiro Neto (2015); which provide diets containing 1.09, 2.18 and $3.27 \mathrm{~mL} / \mathrm{kg}$ of $\mathrm{OE}$ for lambs and also showed no effect on DMI $(1.55,1.48$ and $1.62 \mathrm{~kg} / \mathrm{d}$, respectively), which is consistent with the results of other authors in in vivo studies (Wang et al., 2009). As the diets presented similar chemical composition (Table 1), the lack of effect of the treatments on the nutrient intake was due exclusively to similar DMI (Table 2).

\section{Nutrient digestibility}

The fact that monensin and $\mathrm{OE}$ contents did not affect the nutrients digestibility indicates that these compounds had only a subtle antimicrobial effect, which was sufficient to alter the ruminal fermentation (Table 3 ), without effect on digestibility. Other authors have shared similar results (Borges et al., 2008; Tomkins et al., 2015). Therefore, the data make it clear that in relation to nutrients intake and digestibility, the amounts of monensin evaluated (12.5 or $25 \mathrm{mg} / \mathrm{kg}$ of diet) were appropriate for feedlot lambs. Similarly the use of EO (1 $\mathrm{mL} / \mathrm{kg}$ DM) was also adequate for lambs, which is in accordance with the results of Faleiro Neto (2015). However, it is important to note that the EO tended to decrease the digestibility of $\mathrm{CP}(77.6 \%$ vs $70.2 \%$, $\mathrm{P}=0.13)$ and NDF $(74.4 \%$ vs $64.6 \%$, $\mathrm{P}=0.14)$ for the diets containing monensin and EO, respectively. Some researchers have suggested that EO may decrease the action of proteolytic bacteria in the rumen (Wallace et al., 2002), which may have occurred minimally in the present experiment.

\section{Ruminal SCFA and $\mathrm{pH}$}

The quadratic response of monensin contents to ruminal $\mathrm{pH}$ showed that $12.5 \mathrm{MON}$ was more efficient than $25 \mathrm{MON}$ to increase ruminal $\mathrm{pH}$. Many reports have shown the effectiveness of monensin in increasing the ruminal $\mathrm{pH}$ of lambs receiving diets containing high levels of NFC (Safaei et al., 2014), but all these authors used doses equal to or greater than $25 \mathrm{mg} / \mathrm{kg}$ of diet of monensin and, the data from the present experiment make clear the possibility of using only half dose for lambs, which may contribute to a reduction in the cost of the diet. The lower acetate:propionate ratio and the lowest ruminal concentration of total SCFA in lambs fed with $12.5 \mathrm{MON}$ may explain the higher ruminal $\mathrm{pH}$ (Table 3 ). In addition, it has long been known that monensin plays a role in gram-positive bacteria (Richardson et al., 1976), which in turn produce lactic acid in the rumen, which 
is mainly responsible for ruminal $\mathrm{pH}$. Tung Kung (1993), when evaluating the growth of lactate-producing bacteria, such as Streptococcus bovis and Lactobacillus acidophilus, observed that they grew at $\mathrm{pH} 5.5$ and 6.5 , but when they added monensin to the diet the populations of these bacteria reduced. Thereby, it is possible to suggest that rumen lactate production was lower in animals fed $12.5 \mathrm{MON}$.

The EO had excellent potential of use as additive, since it increased ruminal $\mathrm{pH}(\mathrm{P}=0.06)$ when compared to control diet. In addition, it had an effect on ruminal $\mathrm{pH}$ equivalent to the monensin (Table 3 ), which shows that secondary plant compounds may be as effective as antibiotics in controlling ruminal acidosis in animals fed high concentrated diets, in agreement with other results of the literature (Benchaar et al., 2006).

Regarding the SCFA profile in the rumen, both the half the dose of monensin and EO showed an important antimicrobial activity, since important alterations were observed (Table 3). Regarding monensin, it is worth mentioning the quadratic response on the acetate:propionate ratio, whose lowest value was observed to $12.5 \mathrm{MON}$. This result can be attributed to the lower ruminal concentration of acetate in the animals of this treatment, since the ruminal concentration of propionate was not affected (Table 3 ). It is known that the number and activity of fibrolytic bacteria is directly related to the ruminal concentration of acetate (Varel and Jung, 1986). From this, it is possible to suggest that $12.5 \mathrm{mg} / \mathrm{kg}$ of diet of monensin had a greater effect on fibrolytic microorganism, which would justify the lower concentration of acetate in the animals of these treatments. However, it is worth mentioning that there was no relationship between NDF digestibility and ruminal concentration of acetate in monensin-containing diets
(Table 3). Other authors have observed changes in the ruminal concentration of acetate in dietary situations in which the digestibility of the fiber has not been altered (Ferreira et al., 2011b).

The effect of monensin and EO on decreasing ruminal concentrations of isobutyrate and isovalerate was consistent (Table 3 ). The reductions in the concentrations of branched-chain fatty acids indicate lower rumen deamination (Mackie and White, 1990; Russell, 2002). Literature reports support the findings of the present experiment regarding the probable inhibitory effect of EO on the proteolytic bacteria in the rumen, in this sense, Ferme et al. (2004) concluded that garlic oil modified the profile of the microbial population in vitro, reducing the contribution of Prevotella spp, which is the main species responsible for protein degradation and amino acid deamination in the rumen.

\section{Ingestive behavior}

The fact that monensin or EO did not affect the ingestive behavior (Table 4) (time of ingestion, rumination and chewing) supports the idea that changes in rumination fermentation characteristics (Table 3) were due exclusively to the action of the additives on ruminal microorganisms. One of the concerns regarding the use of additives is their palatability and consequent acceptance by the animals (Mertens, 1994). Therefore, the lack of effect of the two concentrations of monensin and EO on nutrient intake and ingestive behavior make clear the good acceptance of these compounds by lambs.

According to Van Soest (1994), the increase in NDF content of the diet promotes an increase in rumination and chewing time due to the greater need for fiber processing. Thus, rumination time is highly correlated to NDF intake. In the present experiment the diets presented similar NDF content, which justifies the 
similarity in the ingestive behavior of the animals (Table 4).

\section{Biochemical characteristics and erythrogram}

The ALT is widely distributed in the body and when a hepatic disorder occurs, detects an increase in its activity in serum as a result of cholestasis by obstruction of the bile canaliculi. In addition, gastrointestinal disturbances may be associated with an increase in the serum activity of this enzyme (Kerr, 2003; Kanejo, 2008), especially when the animals are in ruminal acidosis, where liver abscesses are frequent (Nagaraja and Chengappa, 1998). From this, it is suggestive to say that the hepatic health of the animals improved progressively in response to the increased supply of monensin, in addition to which the EO also consistently improved this parameter.

The inclusion of monensin in the diets resulted in a linear decrease in plasma glucose concentration. In addition, in the comparison with the treatment containing essential oil, animals receiving monensin also had lower plasma glucose concentration (Table 5). It is known that the main gluconeogenic substrate in ruminants is propionate, some researchers indicate that 40 to $60 \%$ of glucose in ruminants comes from propionate (Leng et al., 1967; Wiltrout et al., 1972), however in the present experiment there was no direct relation between the ruminal concentration of propionate and the plasma glucose concentration, since the plasma concentration of propionate was not affected by the treatments (Table 3 ). This result may have occurred because not all propionate produced by the rumen is used for gluconeogenesis, since a fraction of this compound can be lost or metabolized by the rumen epithelium (Yost et al., 1977). It is also known that propionate has high relation with the DMI, as in the present study there was no effect of the diets on the consumption, this result can explain the lack of relation of propionate with the plasma concentration of glucose.

The erythrogram of the lambs was not affected by the inclusion of monensin or EO in the diets.

\section{Parasitological analysis}

It was observed a higher number of EGF (262.5) to animals that received $12.5 \mathrm{MON}$, however, the EGF values of all treatments are within the range suitable for good animal health, considering that infections of up to 350 EGF are considered mild (Kumar and Hafeez, 1999), which explains the similarity in the erythrogram and other blood parameters of the animals (Table 5).

\section{CONCLUSIONS}

Half of the daily dose of monensin was more effective at increasing ruminal $\mathrm{pH}$ than the full dose with no negative reflection on nutrient intake and digestibility, as well as on the ingestive behavior. Thus, $12.5 \mathrm{mg} / \mathrm{kg}$ of diet of monensin may be indicated for lambs feed high-concentrate diet.

Essential oil proved to be a good natural source of substitution for ionophore in the manipulation of ruminal fermentation. From the observed effects on ruminal fermentation characteristics the antimicrobial effect of essential oil was evident. The positive effect of essential oil on ruminal $\mathrm{pH}$ in relation to the control treatment and the similarity in relation to monensin demonstrates the real possibility of using this substance as a feed additive in high concentrate diets for lambs.

\section{ACKNOWLEDGMENTS}

The authors are grateful to Araucária Foundation for the first author scholarship and Agronomic Institute of Paraná - IAPAR for installation. 
Appreciation is extended to undergraduate students for assistance and animal care during this study.

\section{REFERENCES}

ABIEC. [2016]. Brazilian Association of Meat Exporters. Available at: http://www.abiec.com.br/. Access in: 07/15/2017.

ABRAR, A.; TSUKAHARA, T.; KONDO, $M$.; et al. Effect of monensin withdrawal on rumen fermentation, methanogenesis and microbial populations in cattle. Animal Science Jornal, v. 86, p. 849854, 2015.

ARAUJO, R.C. Essential oils from Brazilian plants as manipulators of in vitro ruminal gas production fermentation. 2010. Piracicaba, 178p. Thesis (Doctorate in Animal Science) "Luiz de Queiroz" College of Agriculture, State University of São Paulo.

ARAUJO, R.C.; PIRES, A.V.; SUSINN, I.; et al. Milk yield, milk composition, eating behavior, and lambs performance of ewes fed diets containing soybean hulls replacing coastcross (Cynodon species). Journal of Animal Science, v.86, n.12, p.3511-3521, 2008.

ASSOCIATION OF OFFICIAL ANALYTICAL CHEMISTRY - AOAC. Official methods of analysis. 16.ed. Arlington: AOAC International, 1995. 1025p.

BENCHAAR, C.; DUYNISVELD, J.L.; CHARMLEY, E. Effects of monensin and increasing dose levels of a mixture of essential oil compounds on intake, digestion and growth performance of beef cattle. Canadian Journal of Animal Science, v.86, n.1, p. 91-96, 2006.

BERNARDES, G.M.C.; CARVALHO, S.; PIRES, C.C.; et al. Consumo, desempenho e análise econômica da alimentação de cordeiros terminados em confinamento com o uso de dietas de alto grão. Arquivo Brasileiro de Medicina Veterinária e Zootecnia, v.67, n. 6, p. 1684-1692, 2015.

BORGES, A.M.; ALVES, B.R.C.; RUAS, J.R.M. Early induction of ovulation in postpartum anestrous $F 1$ Holstein $x$ Zebu crossbred dairy cows. In: INTERNATIONAL CONGRESS ON ANIMAL REPRODUCTION, 15., 2008. Budapeste. Proceedings... Budapeste: Reproduction in Domestic Animals, 2008. p. 33.

BOUCQUÉ, Ch.V.; FIEMS, L.O.; COTTYN, B.G.; et al. Monensin-sodium as a performance-promoting additive for fattening bulls and its impact on carcass and meat quality characteristics. Animal Feed Science and Technology, v. 7, n. 4 p.401-410, 1982.

CALSAMIGLIA, S.; BUSQUET, M.; CARDOZO, P.W.; et al. Invited review: Essential oils as modifiers of rumen microbial fermentation. Journal Dairy Science, v.90, n.6, p.2580-2595, 2007.

FALEIRO NETO, J.A. Impact of essential oils of Brazilian plants on parameters of ruminal fermentation, digestibility and nitrogen balance in sheep. 2015. Pirassununga, 151p. Thesis (Doctorate Nutrition and Animal Production) - Faculty of Veterinary Medicine and Animal Science, State University of São Paulo.

FERME, D. The effects of plant extracts on microbial community structure in a rumen-simulating continuous-culture system as revealed by molecular profiling. Folia Microbiological, v.49, p.151-155, 2004.

FERREIRA, E.M.; PIRES, A.V.; SUSIN, I.; et al. Growth, feed intake, carcass characteristics, and eating behaviour of feedlot lambs fed high-concentrate diets containing soybean hulls. Journal Animal Science, v.89, p.4120-4126, 2011a. 
FERREIRA, E.M.; PIRES, A.V.; SUSIN, I.; et al. Apparent digestibility, nitrogen balance and ruminal constituents in lambs fed high-concentrate diets containing soybean hulls. Journal of Animal Science, v.89, p.4127-4133, 2011b.

FERREIRA, E.M.; PIRES, A.V.; SUSIN, I.; et al. Lamb performance, milk production and composition from ewes supplemented with soybean of partially replaced by fish oil blend. Livestock Sci., v.163, p.51-61, 2014.

FERREIRA, E.M.; PIRES, A.V.; SUSIN, I.; et al. Nutrient digestibility and ruminal fatty acid metabolism in lambs supplemented with soybean oil partially replaced by fish oil blend. Animal Feed Science and Technology, v.216, p. 3039, 2016.

GASTALDELLO JUNIOR, A.L.; PIRES, A.V.; SUSIN, I.; et al. Limestone with different particle size and sodium bicarbonate to feedlot lambs fed high grain diets with or without monensin. Small Rum. Res., v.114, n.1, p.80-85, 2013.

GASTALDELLO JUNIOR, A.L.; PIRES, A.V.; SUSIN, I.; et al. Desempenho e características de carcaças de cordeiros alimentados com dietas contendo alta proporção de concentrado adicionadas de agentes tamponantes. Revista Brasileira de Zootecnia, v.39, n.3, p.556-562, 2010.

GORDON, H.M.; WHITLOCK, H.V. A new technique for counting nematode eggs in sheep feces. Journal of Council of Science and Industry Research, Australia, v.12, n.1, p. 5052, 1939.

IBGE. [2015]. Brazilian Institute of Geography and Statistics. Municipal Livestock Production. Available at: www.ibge.gov.br. Access in: 45 06/15/2017.
KANEJO, J.J.; HARVEY, J.W.; BRUSS, M.L. Clinical Biochemistry of domestic animals. Elsevier, 2008. 918p.

KERR, M.G. Exames Laboratoriais em medicina Veterinária. Bioquímica Clínica e Hematologia. 2.ed. Roca: São Paulo, 2003 436p.

KRAUSE, K.M.; FOTZEL, G.R. Understanding and preventing subacute ruminal acidosis in dairy herds: a review. Animal Feed Science and Technology, v. 126, p. 215-236, 2006.

KUMAR, B.V.D.; HAFEEZ, MD. Prevalence of sub-clinical coccidiosis in lambs in and around Thirupathi, Andhra Pradesh. J. Vet. Parasitol., v.13, p. 167-169, 1999.

LENG, R.A.; STEEL, J.W.; LUICK, J.R. Contribution of propionate to glucose synthesis in sheep. Biochemical Journal, v.103, n. 3, p.785-790, 1967.

MACKIE, R.I.; WHITE, B.A. Recent advances in rumen microbial ecology and metabolism: Potential impact on nutrient output. Journal Dairy Science, v.73, n.10, p.2971-2995, 1990.

MAIA, M.O. Effect of the addition of different sources of vegetable oil on the diet of sheep on the performance, composition and profile of fatty acids in meat and milk. 2011. Piracicaba, 140p. Thesis (Doctorate in Animal Scince) - "Luiz de Queiroz" College of Agriculture, State University São Paulo.

MERTENS, D.R. Regulation of forage intake. In: FAHEY JR., G.C. Forage Quality, Evaluation, and Utilization. American Society of Agronomy. National Conference on forage Quality, Evaluation and Utilization. Madison: American Society of Agronomy, 1994. P.450-493.

NAGARAJA, T.G.; CHENGAPPA, M.M. Liver abscess in feedlot cattle: A review. Journal of Animal Science, v.76, p.287-298, 1998. 
NASROLLAHIA, S.M.; GHORBANI, G.R.; ZALI, A.; et al. Feeding behaviors, metabolism, and performance of primiparous and multiparous dairy cows fed high-concentrate diets. Livestock Science, v.198, p.115-119, 2017.

National Research Council, 2007. Nutrient requirements of small ruminants: sheep, goats, cervids, and new world camelids. Washington: National Academic Press, 292 p.

PERRY, S.V.; COLE, H.A.; FREARSON, N.; MOIR, A.J.G.; MORGAN, M.; PIRES, E. Molecular Basis of Motility. Springer-Verlag: Berlin and New York, 1976. p. 107-121.

RICHARDSON, L.F.; RAUN, A.P.; POTTER, E.L.; et al. Effect of monensin on rumen fermentation in vitro and in vivo. Journal of Animal Science, v.43, n.3, p.657-664, 1976.

RUSSELL, J.B. Rumen microbiology and its role in ruminant nutrition. Ithaca, 2002. 119p.

SAFAEI, KH.; TAHMASBI, A.M.; MOGHADDAMC, GH. Effects of high concentrate: forage ratio diets containing monensin on the management of ruminal acidosis in Gezhel lambs. Small Ruminant Research, v. 121, n.2-3, p.183-187, 2014

SANTOS, J.E.P. Metabolic disorders. In: BERCHIELLI, T.T.; PIRES, A.V.; OLIVEIRA, S.G. Nutrition of ruminants. 2.ed. Jaboticabal: Funep, 2011, Cap. 15, p. 423-492.

SAS institute, 1999. SAS Systems for windows, Version 8.2 ed. SAS Inst., Cary, NC.

TOMKINS, N.W.; DENMAN, S.E.; PILAJUN, R.; et al. Manipulating rumen fermentation and methanogenesis using an essential oil and monensin in beef cattle fed a tropical grass hay. Animal Feed Science and Technology, v.200, p.25-34, 2015.
TUNG, R.S.; KUNG JR, L. In Vitro Effects of a Thiopeptide and monensin on ruminal fermentation of soluble carbohydrates. Journal Dairy Science, v.76, n.4, p.1083-1090, 1993.

VAN SOEST, P.J. Nutritional ecology of the ruminant. 2 nd Edition. CoDMtock: Cornell University Press, 1994. 476 p.

VAN SOEST, P.J.; ROBERTSON, J. B.; LEWIS, B.A. Symposium: carbohydrate methodology, metabolism, and nutricional implications in dairy cattle: methods for dietary fiber, neutral detergent fiber, and nonstarch polysaccharides in relation to animal nutrition. Journal of Dairy Science, v.74, p. 3583-3597, 1991.

VAREL, V.H., JUNG, H.J. Influence of forage phenolics on ruminal fibrolytic bacteria and in vitro fiber degradation. Applied and Environmental Microbiology, V. 52, n.2, p. 275-280, 1986.

WALLACE, R.J.; MCEWAN, N.R.; MCINTOSH, F.M.; et al. Natural products as manipulators of rumen fermentation. Asian-Australian Journal Animal Science, v.15, n. 10, p.14581468, 2002.

WANG, C.J.; WANG, S.P.; ZHOU, H. Influences of flavomycin, ropadiar, and saponin on nutrient digestibility, rumen fermentation, and methane emission from sheep. Animal Feed Science and Technology, v.148, n.2-4, p.157-166, 2009.

WEISS, W.P.; CONRAD, H.R.; ST. PIERRE, N.R. A theoretically-based model for predicting total digestible nutrient valued of forages and concentrates. Animal Feed Science and Technology, v. 39, p. 95-110, 1992.

WILTROUT, D.W.; SATTER, L.D. Contribution of propionate to glucose synthesis in the lactating and nolactating 
cow. Journal Dairy Science, v.55, n.3, p.307-317,1972.

YOST, W.M.; YOUNG, J.W. Stephen P.; et al. Gluconeogenesis in Ruminants: Propionic Acid Production from a HighGrain Diet Fed to Cattle. The Journal of Nutrition, v.107, n.11, p.2036-2043, 1977. 